\title{
CONTRIBUTIONS OF OPERATIONS MANAGEMENT TO THE COMPETITIVENESS OF THE BRAZILIAN ELECTRONICS SECTOR
}

\author{
Ana Beatriz Lopes de Sousa Jabbour ${ }^{1}$, Charbel José Chiappetta Jabbour²
}

\author{
UNESP - Univ. Estadual Paulista - Departamento de Engenharia de Produção, Avenida \\ Engenheiro Luiz Edmundo Carrijo Coube, 14-01, Bauru, SP-Brazil CEP 17033360 \\ E-mail: 1ablsjabbour@gmail.com; 2prof.charbel@gmail.com (corresponding author)
}

Received 01 August 2011; accepted 06 August 2012

\begin{abstract}
The objective of this paper is to identify and analyze various aspects of the internal and external operations management of Brazil's electronics sector and to consider the opportunities for and the threats to increasing the competitiveness of its participation in the global supply chain. To address this shortage in the literature, a survey of Brazilian Electric and Electronic Industry Association (ABINEE) companies was conducted. The collected data were complemented with secondary data to establish an overall view of the electronics sector in Brazil. The results suggest that electronics product assembly companies have the opportunity to invest more in information technology to expand process integration, plan and develop products, integrate customers, and maintain rather than expand their supply chain practices. The alignment between internal and external operations management becomes important in this context. The originality of this paper lies in its clarification of operations management in an economically important sector and the insight it provides to academics, practitioners and policy makers involved in the domestic and international electronics sector.
\end{abstract}

Keywords: Operations Management; Electronics sector; Supply Chain Management; Brazil.

Reference to this paper should be made as follows: Jabbour, A. B. L. S.; Jabbour, C. J. C. 2013. Contributions of operations management to the competitiveness of the Brazilian electronics sector, Journal of Business Economics and Management 14(Supplement 1): S358-S376.

JEL: M11, L63, D20, L21.

\section{Introduction}

Operations management is responsible for ensuring efficiency and efficacy in the transformation process (Prentis 1987) using a set of policies and practices that are defined and implemented by a company and are aimed at satisfying the market (Fleury 1999). At present, operations management must address the growing complexity of production systems, deep changes in industry structure, and the different roles that must be performed by different companies in the supply chain. These roles are influenced by factors such as information technology (IT) and globalization (A. Fleury, M. T. Fleury 
2007). According to Prentis (1987), changes occurring in the market and in technology demand the correct positioning of production systems.

According Sohal et al. (1999), in recent decades, industries in many countries have been analyzed to examine strategies, and various production processes were adopted. The objective of many of these studies was to identify the "best" strategies and practices that yield superior performance. However, Brazil's electronics sector, which is responsible for $4 \%$ of the GDP (Abinee 2010a), has yet to have its operations management analyzed extensively; the available studies (Gonçalves 1997; Nassif 2002; Gutierrez, Alexandre 2003; Cnm, Dieese 2010; Chami Batista 2010) mainly focus on its macroeconomic trajectory.

Based on a search of the most prestigious databases for Brazilian scientific papers that cite only the electronics sector, there is little information on how the sector conducts its internal and external operations (Fensterseifer, Bastos 1989; Belle 1991; Slongo 1996; Martins 2001; Talamo, Carvalho 2004; Mafra, Grisci 2004; Jansen et al. 2005; Araujo, Oliveira 2006; Hauser et al. 2007; Vianna et al. 2007; Balbinot, Marques 2009). However, a search for articles in international databases reveals a more intense and detailed discussion about the electronics sectors in several countries. For example, a study on research and development maturity in emerging countries (Tan, Hwang 2002), a proposal for implementing production management systems (Helo 2004), a proposal for a quality management model (Yeung et al. 2005), a study on intermediation in the electronic sector (Shunk et al. 2007) and a study on supply chain management (Singh, Al-Hakim 2009) can be found. Thus, there is a need to understand operations management in various cultural/national environments (Alas et al. 2010).

Considering the knowledge gap in Brazil regarding the state of the art in the global electronics sector, this paper proposes to answer the following question: "What are the main aspects of Brazil's electronics sector, particularly with regard to internal (operations strategy, ways of meeting customer demands, use of information technology and managerial actions) and external (means of relating to customers and suppliers and the adoption of supply chain management practices) operations that offer opportunities for and threats to increasing the competitiveness of the sector's participation in global supply chain?" The main objective of this study is to identify and analyze the aspects of internal and external operations management of Brazil's electronics sector and to consider the opportunities for and the threats to increasing the competitiveness of its participation in the global supply chain.

The data collection procedure used was a survey of companies affiliated with ABINEE. The research was conducted in the second half of 2009.

\section{Literature review}

\subsection{Brazil's electronics complex}

An electronic industrial complex is a set of industrial segments and sectors characterized by a common technical base (microelectronics) (Nassif 2002; Gutierrez, Alexandre 2003; Hauser et al. 2007). The electronic complex is divided into four segments: computers, telecommunications, automation and electronic consumer goods (Gonçalves 1997). 
To Gutierrez and Alexandre (2003), this complex is very important because electronics are involved in almost every economic activity (the production of capital goods, consumer goods, energy, etc.). A study by Cnm and Dieese (2010) affirms that the quality and power of the electronics sector to offer products to other economic sectors are crucial to national development.

In Brazil, the electronics sector has gone through different phases from its inception to the present day. Nassif (2002) states that between the 1950s and the first half of the 1970s, Brazil did not have a sufficient number of companies to shape an electronic complex. During this period, the Brazilian electronic sector was characterized by the activity of multinationals.

In the beginning of the 1970s, an impressive expansion in consumer electronics occurred, driven by tax and fiscal incentives granted to companies that established business in the Manaus Free Zone (ZFM). The city of Manaus is located in the north of the country near the Amazon Forest. The intention was to make Brazil an exporter of electronic products and to replace imports. The objective of the ZFM was to attract branches of multinational companies, but as a result of this dynamic, several domestic capital companies were excluded from the market (Nassif 2002). The lack of competitiveness of the final goods produced in the ZFM did not permit exports to large markets, dooming the promising domestic production market to failure. The reasons for this lack of competitiveness include the fact that the region did not (and does not) have adequate infrastructure (poor road conservation), skilled labor or the appropriate distribution logistics (it is far from consumer and production centers), which resulted in higher costs, even with the fiscal incentives (Chami Batista 2010).

In the 1980 s, the country adopted an extreme industrial policy that had direct effects on the electronic product sector. The restrictiveness of trade policies in the telecommunications and computer sectors are noteworthy, as is the prohibition of a long list of consumer electronic goods imports (Chami Batista 2010).

However, with trade liberalization in 1990, imports grew, and most domestic companies left the market; the few that remained stayed in specialized niches (Nassif 2002). As a consequence, Brazil is currently experiencing a negative trade balance in the electronics sector.

An incentive for the sector, known as the Computer Law, Law Number 8.248, has been in effect since 2001. This law stipulates that companies that invest a percentage of their gross revenues in research and development in the computer field can request tax breaks (Brasil 2010a).

As a result of the electronics sector's trajectory over the past 50 years, the sector has the following characteristics:

- The basic production process is restricted to product assembly using a set of components that are imported; therefore, there is almost no production of electronic components. Thus, there is no complete cycle of integrated circuit production (components that increasingly concentrate the final good's functionalities) (Hauser et al. 2007); 
- The products manufactured in Brazil are designed abroad, and consequently, the component design and engineering activities have already been completed. Brazil then adapts the multinational products and services, customizing and nationalizing them for the local market (Kronmeyer Filho et al. 2004); and

- The dynamism of the electronic complex is tied to the successive product life cycle, whether radical or incremental, and in Brazil, incremental innovations related to product functionality and quality predominate (Gonçalves 1997).

Finally, according to Abinee (2010b), the sector's retail activity is very concentrated and exercises great bargaining power. The majority of suppliers (70\%) are local, small- to medium-sized, and rely on the import of foreign components, which constitute approximately $30 \%$ of the raw materials. There are many destinations for the final products; $7 \%$ are exported (Abinee 2010b). The structure of the electronic supply chain is summarized in Figure 1.

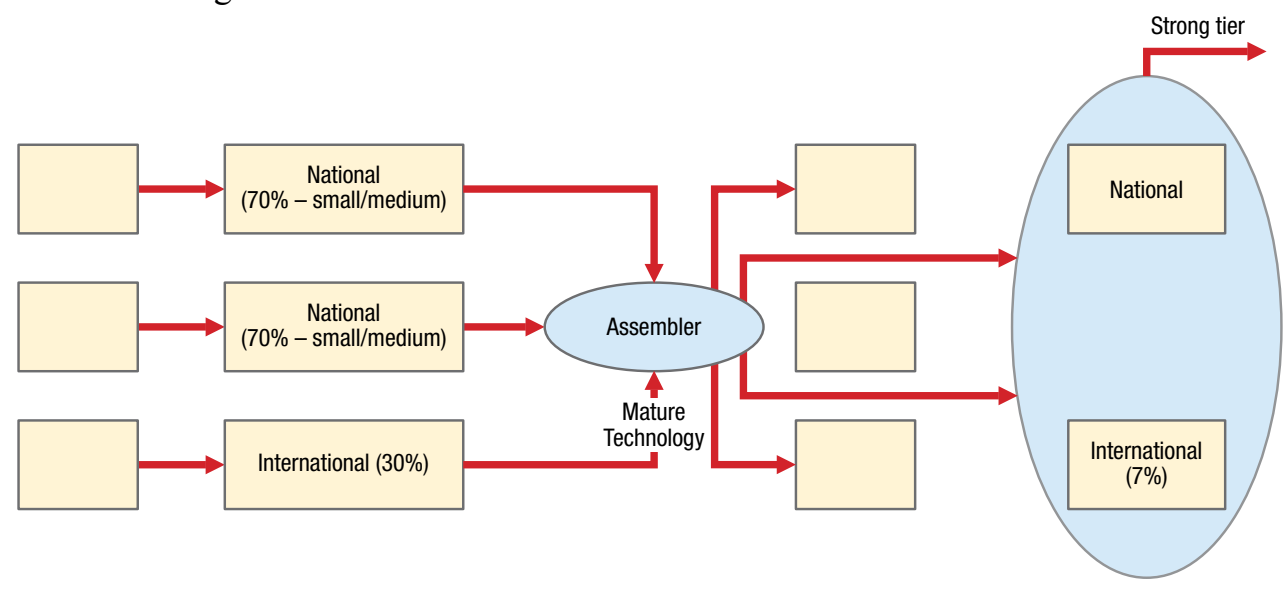

Fig. 1. Brazilian electronics SC structure

Therefore, in Brazil, the electronics sector experiences opportunities for and threats to increasing the competitiveness of its participation in global supply chain. These opportunities and threats require better knowledge of operations management and competitiveness.

\subsection{Aspects of operations management}

Considering the complex responsibilities of operations management (Slack et al. 1996), this paper also poses questions related to understanding the strategic objectives of production from a production strategy content perspective. These questions have implications for the internal management (production planning) and the external management (supply chain management) of operations as the Brazilian electronics sector seeks to increase its participation in global supply chains.

In this research, operations management is defined as the planning, direction and control of processes that transform inputs into services and products for internal and external customers (Krajewski et al. 2009). 
Operations management performs based on a competitive strategy. One of the main activities of this strategic process is defining the competitive priority of operations. Competitive priorities (CPs) are defined as the translation of customers' needs, that is, the performance objectives for production. In general, these needs include quality, costs, flexibility and delivery (Hayes, Wheelwright 1984).

CPs inform some decisions that solidify operations management, whether they are internal or external. One of the main issues concerning internal operations is production planning and control (PPC). PPC concerns how the company organizes, allocates and distributes its production resources (people, machines, time) to serve its customers (volume, mix, deadline, etc.). PPC can fill customers' orders in several ways: make to stock (MTS), assembly to order (ATO), make to order (MTO) and engineer to order (ETO).

A set of information technology (IT) and managerial actions have been adopted to computerize PPC, such as Enterprise Resource Planning (ERP), electronic kanban (controlling stock via the Internet), Collaborative Planning, Forecasting and Replenishment (CPFR), Vendor Managed Inventory (VMI) and in-plant representatives.

In external operations, an important issue is the degree of vertical disintegration, that is, how the organization manages its supply chain (SC). This management implies establishing and maintaining relationships with customers and suppliers and implementing supply chain management ( $\mathrm{SCM}$ ) practices.

Supply chain management is an integrative approach that starts with materials planning and control, logistics, services and information flows from suppliers to producers and final users (Fantazy et al. 2010). SCM practices are defined as a set of activities performed by an organization to promote effective management of its SC (Li et al. 2005; Li et al. 2006; Koh et al. 2007). Jabbour et al. (2011) consider SCM practices to consist of the following: (a) the integration of SC for support in PPC, (b) the sharing of information about products and strategic guidelines, (c) strategic relations with customers and suppliers, and (d) support for customer orders. Each category has a set of variables. We conducted empirical research to discuss these concepts in the Brazilian electronics sector.

\section{Methodology}

\subsection{Study subjects}

The companies studied in this paper are members of the Brazilian Association of Electric and Electronic Industries (ABINEE), which represents Brazil's electronic sectors. Founded in 1963, the ABINEE has 552 national and multinational member companies.

\subsection{Data collection}

This is a quantitative study that used an e-mail survey to obtain data.

The data collection instrument was a questionnaire with closed and multiple-choice questions. It was divided into four sections: the first characterized the companies' profiles, the second measured the degree of importance placed on competitive priorities 
with regard to production, the third verified the degree of SCM practice implementation and identified the type of relationship adopted with the other tiers, and the fourth listed some IT and managerial actions adopted at the companies that responded.

Section 1 of the questionnaire uses a nominal scale and deals with issues such as company size. According to Sebrae (2009), in Brazil, one way of classifying company size is based on the number of employees. This questionnaire used four categories: microcompany (1 to 19 employees), small company (20 to 99 employees), medium company (100 to 499 employees), and large company (500 or more employees). This section also identified the responding companies' positions in their main SCs, their bargaining power in the chain; and how they filled customers' orders.

Section 2 of the questionnaire, based on a literature review of CP, included 13 questions and used a 5-point Likert scale (1 - extremely irrelevant to 5 - extremely relevant).

Section 3 adopted the questions validated by Jabbour et al. (2011) to measure the degree of implementation of SCM practices using 22 statements regarding SCM practices that were scored on a Likert scale ( 1 - not implemented to 5 - completely implemented). Spekman et al. (1998)'s concepts were adopted for understanding the company's relationship with the other tiers in the chain. Finally, there were questions about the set of IT and managerial processes adopted at the companies (Barbosa, Musetti 2010).

This survey adopted a self-managed questionnaire as the data-collection instrument. The self-managed questionnaire was pretested before being sent to the analysis units. Synodinos (2003) affirms that the questionnaire test is essential to identifying questions that need to be rewritten. The pretest for this survey was conducted in two steps. The first was with operations management professors and the second was with company managers.

The questionnaire was deemed appropriate (as a result of respondent feedback and Cronbach's alpha). Data were collected in 4 steps. The first step was to contact the ABINEE public relations department to obtain an updated database of its members. The second step began with the name and e-mail of each company's operations manager. This step consisted of formatting the questionnaire so that it would be easy to access and to answer. Internet services were used to formulate a home page with the questionnaire content. The third step was to send personalized e-mails using the direct mail mechanism for all ABINEE spreadsheet contacts. E-mails were sent to the 552 registered companies. However, 20 were returned for a variety of reasons. The fourth step was to manage the return of questionnaires and to take steps to increase the return rate.

After 44 days had elapsed (from July to mid-September 2009) and three waves of emails had been sent, there was a return rate of $20 \%$ (107 respondents). This return rate was considered adequate (Malhotra, Grover 1998).

\subsection{Data analysis}

Descriptive statistical techniques were adopted. The purpose of descriptive analyses is to understand the frequency distribution of each variable according to its core and dispersion tendency. These analyses are appropriate because they permit an understand- 
ing of the competition foci in the sector (competitive priority), the main SCM practices and the use of IT and managerial actions. The data analyses were performed using the Statistical Package for Social Science (SPSS). Secondary data were also used to complement the analyses (Abinee 2010b),

\section{Results}

\subsection{Characterization of the sample}

In the sample, small (32\%) and medium-sized (42\%) companies predominate; microcompanies represent $10 \%$ of the sample, and large companies represent $16 \%$ (Fig. 2). When classified by their position in the SC, $76 \%$ of the companies are assemblers, $16 \%$ are component suppliers, $5 \%$ are distributors, $2 \%$ are retailers, and $1 \%$ are basic raw material suppliers (Fig. 3).

When classified by bargaining power in the main SC, $81 \%$ consider their customers to be organizations that are able to coordinate or even impose themselves in the chain (Fig. 4).

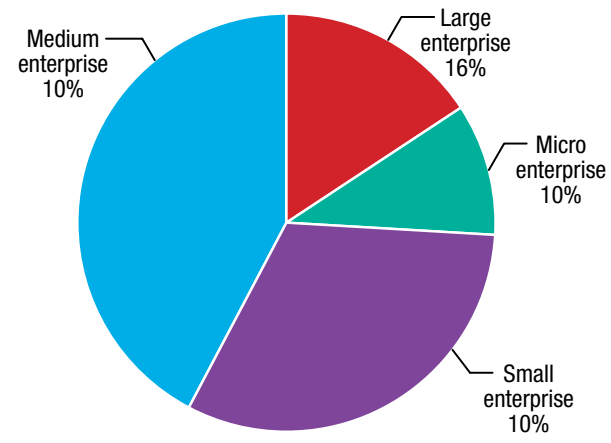

Fig. 2. Stratification by survey sample size

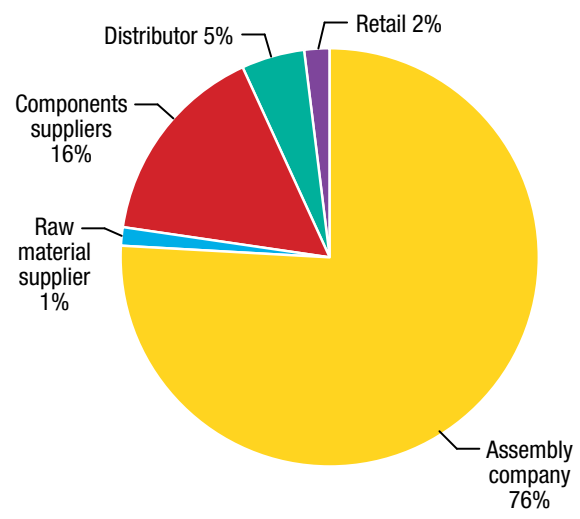

Fig. 3. Stratification of the sample companies according to their position in the main $\mathrm{SC}$

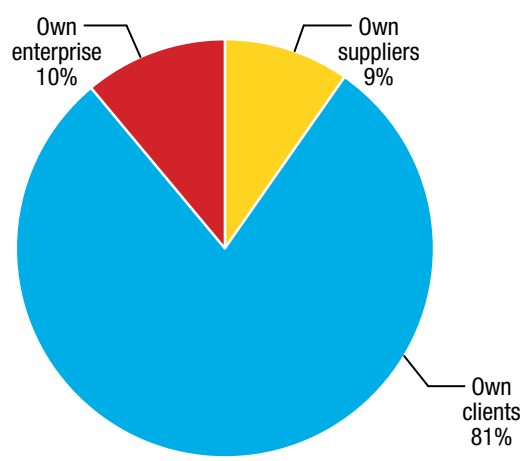

Fig. 4. Distribution of sample according to bargaining power in the main SC 


\subsection{Management of internal operations}

In general, the set of variables related to competitive priorities was deemed relevant to extremely relevant, which can be observed in the variable averages (Table 1). To underscore the most important variables, and thus identify trends in CP selection by companies to compete in their markets, the $25 \%$ of the variables with the highest percentage (alluding to a quartile perspective) was used as a parameter. Thus, 4 variables reflect the CP tendency: defects, technical requirements, delivery dates and functionality. These correspond to the "quality" and "delivery" attributes for the most valorized CPs in the analyzed sample.

Table 1. General CP trends in the sampled companies

\begin{tabular}{lcccccc}
\hline \multicolumn{1}{c}{ Variables } & Average & $\begin{array}{c}\text { Standard } \\
\text { Deviation }\end{array}$ & $\begin{array}{c}\text { Coefficient } \\
\text { of variation }\end{array}$ & Maximum & Minimum & Percentage \\
\hline Prevent Defects & 4.86 & 0.375 & 0.077 & 5.00 & 3.00 & 0.97 \\
\hline $\begin{array}{l}\text { Follow Technical } \\
\text { Requirement }\end{array}$ & 4.74 & 0.572 & 0.12 & 5.00 & 1.00 & 0.95 \\
\hline Meet Delivery Date & 4.70 & 0.499 & 0.106 & 5.00 & 3.00 & 0.94 \\
\hline Functionality & 4.69 & 0.503 & 0.107 & 5.00 & 3.00 & 0.94 \\
\hline Production Cost & 4.64 & 0.573 & 0.123 & 5.00 & 2.00 & 0.93 \\
\hline Product Durability & 4.43 & 0.601 & 0.135 & 5.00 & 3.00 & 0.89 \\
\hline New Products & 4.40 & 0.580 & 0.132 & 5.00 & 3.00 & 0.88 \\
\hline Less Time & 4.31 & 0.605 & 0.140 & 5.00 & 3.00 & 0.86 \\
\hline Production Volume & 4.32 & 0.667 & 0.154 & 5.00 & 2.00 & 0.86 \\
\hline Quick Change in & 4.09 & 0.734 & 0.179 & 5.00 & 2.00 & 0.82 \\
Design & & & & & & \\
\hline Lowest Price & 4.00 & 0.752 & 0.188 & 5.00 & 2.00 & 0.80 \\
\hline Product Range & 3.86 & 0.745 & 0.193 & 5.00 & 1.00 & 0.77 \\
\hline Product Variety & 3.70 & 0.792 & 0.214 & 5.00 & 1.00 & 0.74 \\
\hline
\end{tabular}

The following are characteristics of Brazil's electronics sector: considerable importation of foreign components, approximately $30 \%$ of which are raw materials (Abinee 2010b), domestic competition with imported goods and the non-participation of the sector's products in the complete production cycle. As a result of these characteristics, Brazilian companies focus on quality, which translates into fewer defects, product technical requirements and functionality because this sector generates products that must comply with a series of national and international safety standards and norms to be competitive domestically and to permit possible export. Furthermore, Brazilian companies can innovate in this sector by improving product functionality (Gonçalves 1997). They also focus on delivery; companies in this sector import parts from other countries, so one way to differentiate themselves is to have parts in stock to reliably meet orders because import logistics follow a cycle of approximately 90 days on average. 
Four modalities for meeting customers' needs are adopted by the companies in the sample. The make to order modality is the most used (33.6\%), followed by the assembly to order modality $(27.1 \%)$ and make to stock $(26.2 \%)$. The least-used modality is engineer to order (13.1\%) (Fig. 5). These results demonstrate that this sector imports a considerable percentage of parts and that companies must store the parts to assemble products and fulfill orders. The companies are not designing and producing genuinely new products, as demonstrated by the fact that the engineer to order modality is the least used in the sector's survey sample, revealing the companies' weakness in the area of developing completely new products.

Various IT and managerial actions are being employed in the electronics sector to guide companies' internal and external activities (Fig. 6). ERP is the most adopted IT tool among surveyed companies (75.7\%), followed by the organization of workshops with customers (41.1\%), Electronic Data Interchange (EDI) (31.8\%), workshops with suppliers, and the use of electronic kanban (29\%).

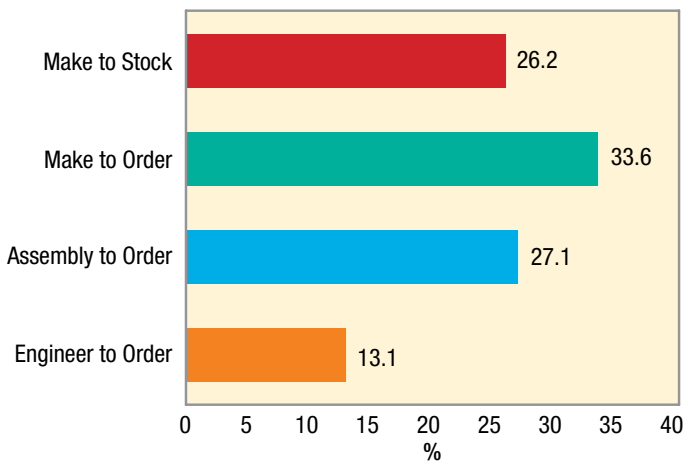

Fig. 5. How customer' orders are fulfilled

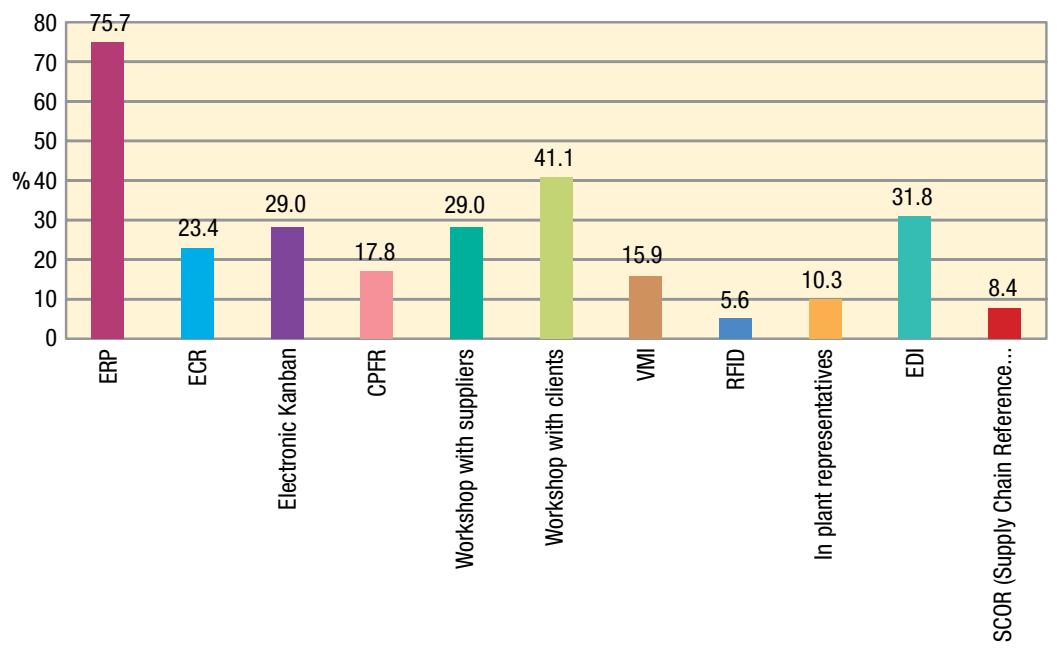

Fig. 6. Actions adopted to facilitate management with customers and suppliers 
With the exception of ERP, the other systems used aim at facilitating the relationship among the company, its customers and its suppliers and the exchange of information. According to Lankford and Johnson (2000), EDI is a form of electronic communication that permits the exchange of information and documents in structured formats that can be processed by a certain type of software. The advantages of EDI include the following (Ferreira, Assumpção 2005): (a) greater visibility for inventory planning and control (which supports the electronic kanban practice), (b) better product delivery planning and (c) agility in transmitting, receiving, and processing orders and reducing errors. In addition to EDI, formal meetings (workshops) that include the company, customers and suppliers help evaluate performance and guide current and future needs regarding products and operational processes. ERP contributes to companies internally by integrating the data from business processes and quickly generating reports for operational and strategic decision making, thus making it possible to appropriately plan for better operational efficiency.

\subsection{Management of external operations}

Of the sample companies, 55.1\% adopt long-term relationships and partnerships in product development activities with important and strategic component suppliers (Fig. 7). There was no clear trend in relationships with the other tiers in the chain; the answers were diverse. For example, with basic raw material suppliers, 38\% of the companies adopt market relationships, whereas 35\% adopt long-term relationships (Fig. 8). Downstream, the trend is not so clear because with intermediate customers (distributors), the relationship was divided; $35 \%$ adopted market relationships, and 35\% adopted longterm relationships (Fig. 9). With final users (retail), 30\% of the respondents consider market relationships to be the most common, $30 \%$ consider long-term relationships to be the most common, and $26 \%$ consider long-term relationships and partnerships in product development activities to be most common (Fig. 10). Relationships with final users are not broadly developed (Fig. 11).

The most prosperous relationships among the studied companies are those with their important and strategic component suppliers $\left(1^{\text {st }}\right.$ tier $)$ and with retail agents $\left(2^{\text {nd }}\right.$ tier customers).

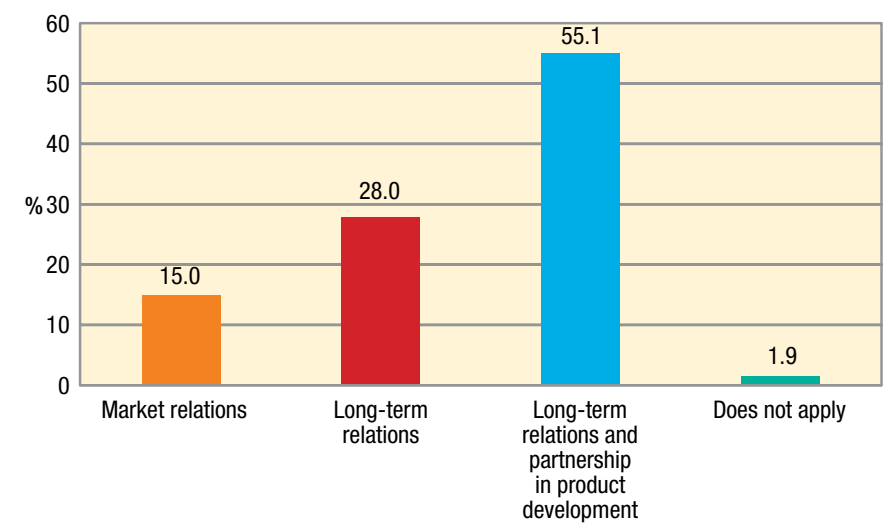

Fig. 7. Company relations with important and strategic component suppliers 
A. B. L. S. Jabbour, C. J. C. Jabbour. Contributions of operations management to the competitiveness ...

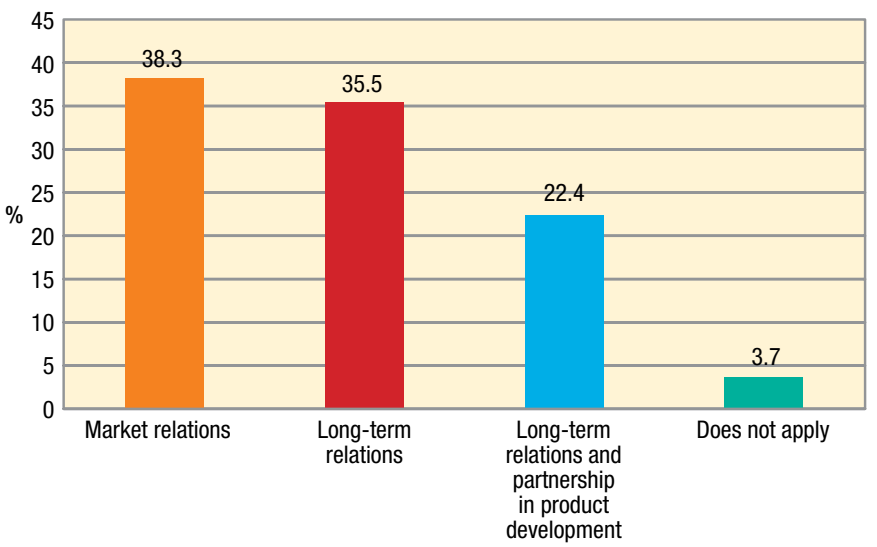

Fig. 8. Company relations with basic raw material suppliers

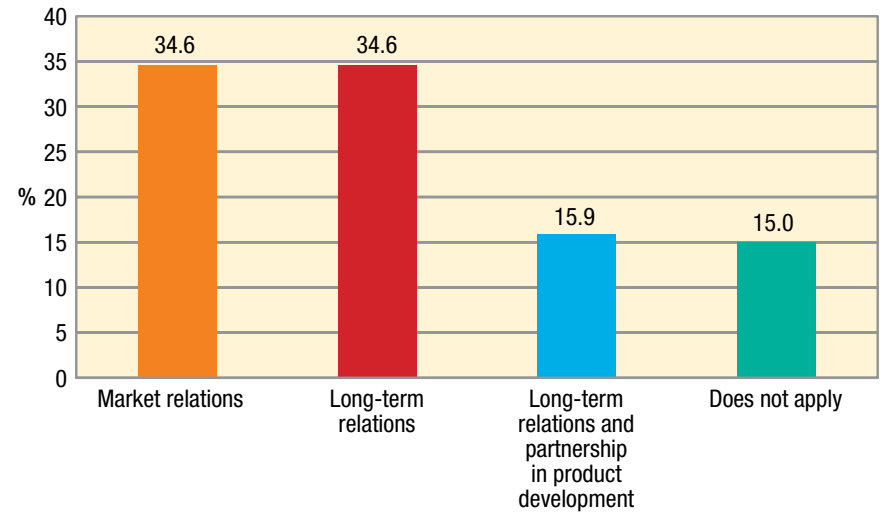

Fig. 9. Company relations with intermediate customers (distributor/wholesaler)

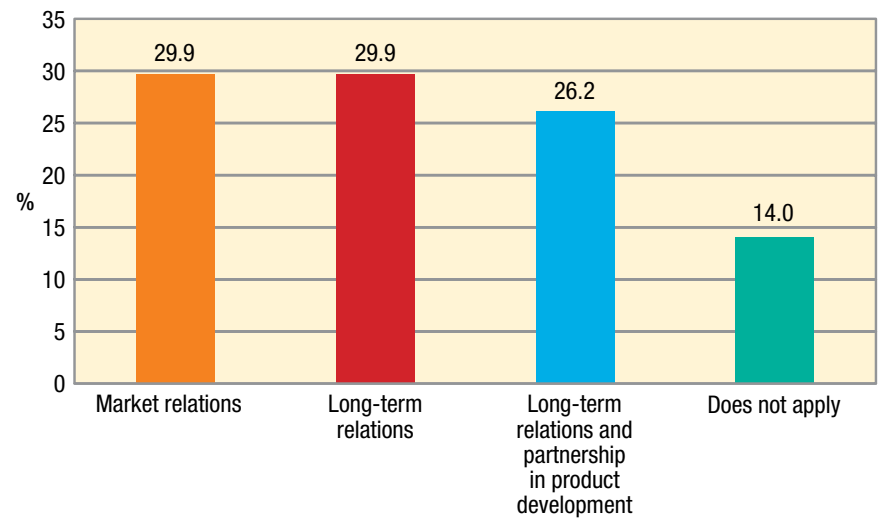

Fig. 10. Company relations with retail agents 


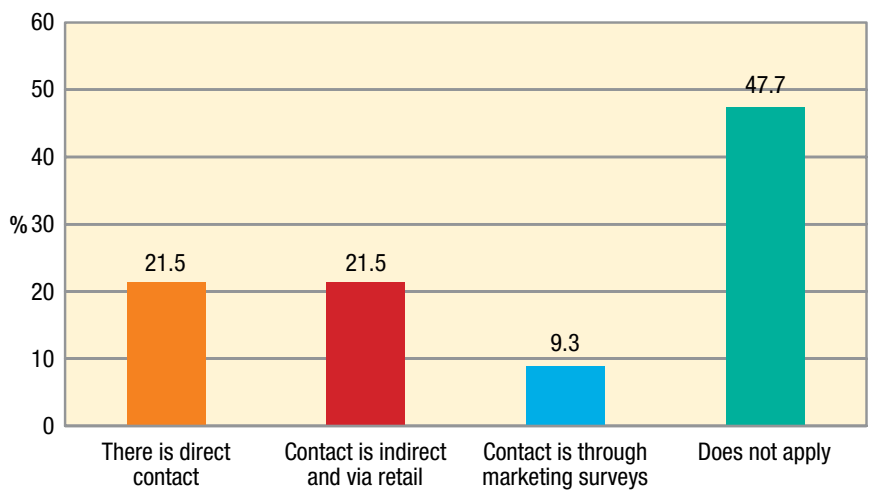

Fig. 11. Company relations with final users (Individuals)

Relationships with component suppliers are predominantly long-term and involve partnerships in product development activities because: (a) the more technologically sophisticated the product, the more strategic the relationship should be, resulting in a reduction in the supplier base (Berry et al. 1994); and (b) assemblers of electronic products constantly redesign their products with the objective of reducing costs and increasing functionality, with great emphasis on supporting suppliers in this process (McIvor, Humphreys 2004).

Relationships with retail customers are predominantly long-term with a tendency toward supporting product development activities. This type of relationship can be explained by the fact that the strongest tier for most of the assemblers studied is downstream in the chain. In other words, these are the companies that influence the rest of the chain (Mouritsen et al. 2003), and it is important to create harmony in operations and in relationships because the company, which is closer to consumers, receives clearer and more immediate information concerning demand and inventory. That is, maintaining a long-term relationship supports the internal efficiency of assembler operations (Berry et al. 1994).

Table 2 depicts the range of SCM practices adopted by companies.

The results indicate that currently, SCM practice adoption is, on average, in the "partially implemented" phase because the average of the medians was 3.05; this value corresponds to "partially implemented" on the Likert scale.

Six variables can be highlighted:

- "Obtaining feedback from final users concerning product fitness";

- "Determining future needs of the customers";

- "Integration of product development activities with suppliers";

- "Collaboration with suppliers in forecasting demand";

- "Consulting customers to support new product decisions";

- "Integration of product development activities with customers".

There are more practices that are directed toward customers. The existence of a wide variety of practices could be evidence for the influence of the chain's strong hierarchy, that is, customers exert power over companies further upstream, which eventually leads 
Table 2. Core and dispersion trends in the adoption of SCM practices

\begin{tabular}{|c|c|c|c|c|c|}
\hline Variable & Average & $\begin{array}{l}\text { Standard } \\
\text { Deviation }\end{array}$ & $\begin{array}{l}\text { Coefficient } \\
\text { of Variance }\end{array}$ & Median & Percentage \\
\hline Client Feedback & 3.77 & 1.112 & 0.294 & 4 & 0.75 \\
\hline Future Needs of Clients & 3.30 & 1.191 & 0.361 & 4 & 0.66 \\
\hline Supplier Integration & 3.32 & 1.364 & 0.411 & 4 & 0.66 \\
\hline $\begin{array}{l}\text { Collaboration Supplier Forecast } \\
\text { Demand }\end{array}$ & 3.24 & 1.338 & 0.413 & 4 & 0.65 \\
\hline Support New Product Client & 3.27 & 1.263 & 0.386 & 4 & 0.65 \\
\hline Client Integration & 3.15 & 1.309 & 0.415 & 3 & 0.63 \\
\hline $\begin{array}{l}\text { Collaboration Supplier Planning } \\
\text { Production }\end{array}$ & 3.09 & 1.438 & 0.465 & 3 & 0.62 \\
\hline $\begin{array}{l}\text { Collaboration Client Forecast } \\
\text { Demand }\end{array}$ & 3.09 & 1.285 & 0.416 & 3 & 0.62 \\
\hline $\begin{array}{l}\text { Collaboration Supplier Planning } \\
\text { Inventory }\end{array}$ & 3.07 & 1.445 & 0.470 & 3 & 0.61 \\
\hline $\begin{array}{l}\text { Collaboration Client Planning } \\
\text { Inventory }\end{array}$ & 3.03 & 1.397 & 0.461 & 3 & 0.61 \\
\hline $\begin{array}{l}\text { Support Supplier Product } \\
\text { Development }\end{array}$ & 3.07 & 1.406 & 0.457 & 4 & 0.61 \\
\hline $\begin{array}{l}\text { Collaboration Client Planning } \\
\text { Production }\end{array}$ & 2.97 & 1.404 & 0.473 & 3 & 0.59 \\
\hline $\begin{array}{l}\text { Consult Supplier Programming } \\
\text { Production }\end{array}$ & 2.92 & 1.487 & 0.510 & 3 & 0.58 \\
\hline $\begin{array}{l}\text { Consult Client Programming } \\
\text { Production }\end{array}$ & 2.87 & 1.530 & 0.533 & 3 & 0.57 \\
\hline Involvement Supplier Plans & 2.79 & 1.419 & 0.508 & 3 & 0.56 \\
\hline Involvement Client Plans & 2.79 & 1.358 & 0.486 & 3 & 0.56 \\
\hline $\begin{array}{l}\text { Communication Strategy Future } \\
\text { Supplier }\end{array}$ & 2.64 & 1.369 & 0.518 & 3 & 0.53 \\
\hline Information Supplier Product Launch & 2.61 & 1.323 & 0.506 & 3 & 0.52 \\
\hline Participation in Client Marketing & 2.53 & 1.383 & 0.546 & 3 & 0.51 \\
\hline Assembly Near Client & 2.38 & 1.527 & 0.641 & 2 & 0.48 \\
\hline Sharing Information Client Cost & 2.12 & 1.385 & 0.653 & 1 & 0.42 \\
\hline Creation of Multifunctional Teams & 2.05 & 1.334 & 0.650 & 1 & 0.41 \\
\hline Average & & & & 3.05 & \\
\hline
\end{tabular}

to greater effort being invested in relationships with and support for customers (Mouritsen et al. 2003).

Figure 12 summarizes the main survey results in relation to the internal and external operations management of companies in Brazil's electronics sector. 


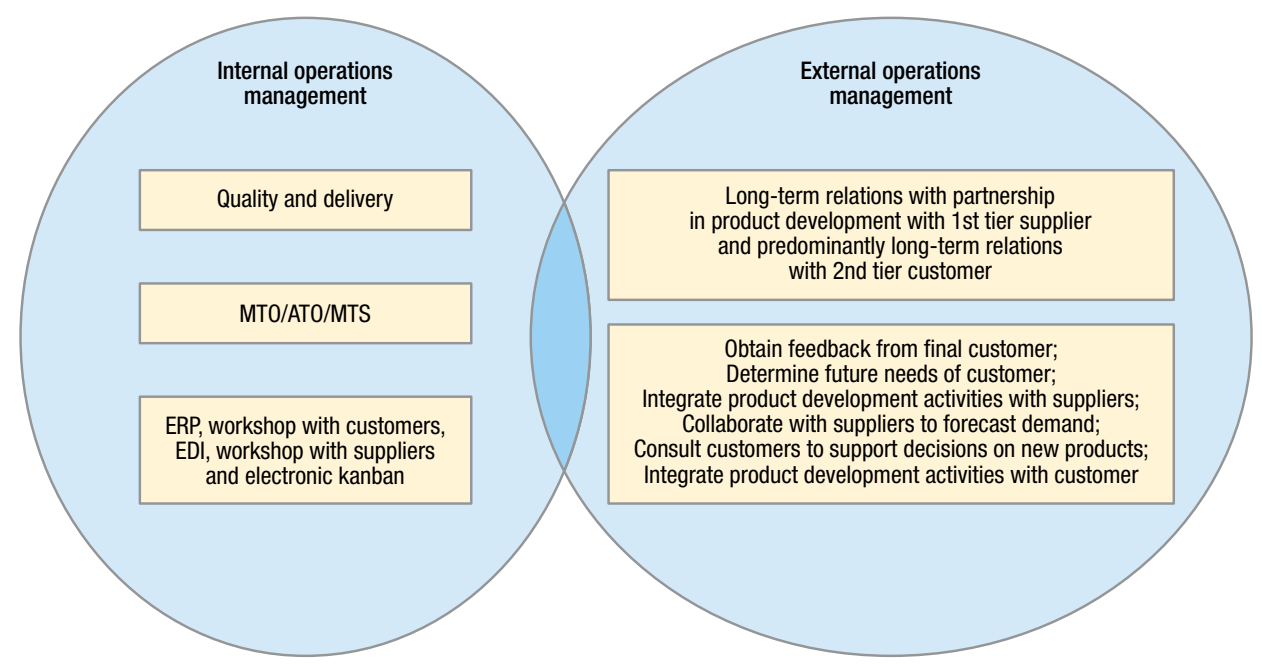

Fig. 12. Summary of the main results regarding operations management in Brazil's electronics sector

\section{Discussions}

Some conclusions can be made regarding internal operations management. Brazilian companies do not compete on costs (lower price), but rather in quality and delivery. This focus on quality and delivery can be used as a tool to address the competition posed by cheaper products originating mainly from Asia (which competes on cost) and to address problems stemming from the exchange rate in setting final product prices.

The most adopted actions to fulfill customer orders (assembly to order and make to stock) are aligned with competitive strategies, especially delivery. Whether companies conclude product assembly after receiving the order or meet the customer's order from products in stock, their lead time for meeting the customer's order is shorter, which makes delivery reliable.

There is evidence of alignment between IT, competitive priorities and the forms of customer service in electronics sector companies (internal operations management). Some technologies are used to control inventory (EDI and electronic kanban) and consequently promote delivery reliability, and others (workshops with customer and suppliers) seek to improve product quality via interaction with customers and suppliers regarding future needs and feedback from the customer.

The alignment between adopted practices and strategies seems less intense (internal and external operations management). For example, the strong tier in the electronics chain is the $2^{\text {nd }}$ tier customer, with whom the assemblers maintain predominantly long-term partnerships in product development, implementing a set of SCM practices that are relevant to product quality (customer feedback and the determination of future needs of the customer) and product development. However, assemblers adopt few IT and managerial procedures and distinguish themselves only in terms of EDI and workshops. Thus, SCM 
practices seem not to be supported by IT, which may indicate that SCM practices can be ineffective in practice.

Another apparent inconsistency occurs upstream from the assemblers' supply chain. The relationship between the assembler and the $1^{\text {st }}$ tier supplier is long-term, with partnerships in product development and the support of IT and managerial actions (EDI, electronic kanban and workshops). However, there is potential to implement more SCM practices to establish a more effective relationship with suppliers, leveraging competitiveness based on quality (product functionality) and delivery, mainly because most of companies are geographically close ( $70 \%$ of raw materials are domestic).

We can identify some opportunities for and threats to a more efficient electronics sector increasing its competitiveness in the global supply chain. These opportunities and threats relate to the search for greater synergy between the management of internal and external operations. Companies can realize this synergy either by expanding the use of IT to support the implementation of SCM practices with customers, who are influential in the chain, or by boosting the use of SCM practices from the IT and management procedures already used with the suppliers.

Brazilian automakers could make use of IT and management actions such as VMI and CPFR, for example, to improve the effectiveness of SCM practices with customers. This would not be so difficult considering that relationships with customers are maintained in the long term in product development partnerships. On the other hand, automakers are already making use of important IT and management procedures with suppliers (electronic kanban, EDI, workshop, ERP), which would facilitate an increased use of SCM practices. Therefore, the search for greater integration of internal and external operations management would enable greater organizational efficiency and may be a way to make these organizations more attractive as a tier in global supply chain. That is, having efficient management and competitive operations can facilitate the further internationalization of the Brazilian electronics industry.

\section{Conclusions}

This paper identified and analyzed aspects of the management of internal and external operations in electronics companies in Brazil. The main results of the research are as follows: (a) companies compete based on product quality and reliable delivery; (b) assemblers maintain long-term relationships and product development partnerships with $1^{\text {st }}$ tier suppliers, whereas they predominantly maintain long-term relationships that tend toward product development partnerships with $2^{\text {nd }}$ tier customers; (c) companies adopt information technologies and managerial actions (ERP, EDI, workshops and electronic kanban) to support internal and external management; (d) the most adopted supply chain management practices, such as obtaining customer feedback, determining customers' future needs, consulting customers to support new product decisions and integrating product development activities with customers, are geared toward customers; (e) there is alignment among the internal operations management aspects that were analyzed; and (f) internal and external operations management are not totally aligned. 
According to Alas, Kraus and Niglas (2010), there is a need to understand operations management in various cultural/national situations; therefore, this research analyzed aspects of operations management in the Brazilian electronics sector, allowing us to highlight the importance of the search for alignment between internal and external operations management to increase the competitiveness of this sector's participation in the global supply chain.

The electronics sector passed through different phases throughout its development process in Brazil. There was government intervention that attempted to leverage the sector; however, these policies were not successful. The consequence was a tendency toward low competitiveness in the sector as a result of the absence of a complete production cycle, resulting in dependence on imported components and products and dependence on multinationals that operated within the country. To overcome years of technological gaps and delays, it is necessary to invest in efficient operations management. Assemblers must invest more in IT to expand the integration of processes, production planning and product development between themselves and their customers and to expand the adoption of SCM practices with suppliers. Brazilian companies should focus on operations management efficiency to overcome the sector's negative history.

We also suggest the creation of policies to encourage the domestic production of integrated circuit components to stimulate the Brazilian production chain. Public authorities could use the lesson of the Manaus Free Zone as an example to avoid committing the same errors and to stimulate other regions of the country, such as the Midwest or Northeast, which are still underdeveloped, for installing electronics component production centers. Development of the electronics sector must follow a logistics infrastructure plan for production flow (highways, railways, ports, etc.), and universities must produce skilled human resources. A stronger industrial pole in these regions would attract private investments, generate jobs and income, and reduce the inequities among regions in Brazil.

This paper has limitations, such as its focus on a single industrial sector in Brazil. However, this example can provide lessons for other countries in similar situations and highlight the importance of public authorities in the effective management of internal and external operations. We hope future studies use the information contained herein to compare Brazil's electronics sector with data from other countries.

\section{Acknowledgement}

This research was supported by Sao Paulo Research Foundation (FAPESP), Brazil (2010/11553-2).

\section{References}

Abinee. 2010a. Associação Brasileira da Indústria Nacional de Elétrica Eletrônica [online], [cited 17 October 2010]. Available from Internet: www.abinee.org.br

Abinee. 2010b. Consolidação da pesquisa com as pequenas e médias empresas do setor eletroeletrônico [online], [cited 17 October 2010]. Available from Internet: http://www.abinee.org.br/ informac/arquivos/pan2010.pdf 
Alas, R.; Kraus, A.; Niglas, K. 2010. Manufacturing strategies and choices in cultural contexts, Journal of Business Economics and Management 10(4): 279-289.

http://dx.doi.org/10.3846/1611-1699.2009.10.279-289

Araujo, A. M. C.; Oliveira, E. M. 2006. Reestruturação produtiva e saúde no setor metalúrgico: a percepção das trabalhadoras, Sociedade e Estado 21(1): 169-198.

Balbinot, Z:; Marques R. A. 2009. Alianças estratégicas como condicionantes do desenvolvimento da capacidade tecnológica: o caso de cinco empresas do setor eletro-eletrônico brasileiro, Revista de Administração Contemporânea 13(4): 604-625.

Barbosa, D. B.; Musetti, M. A. 2010. Logistics information systems adoption: an empirical investigation in Brazil, Industrial Management and Data Systems 110(6): 787-804.

http://dx.doi.org/10.1108/02635571011055054

Belle, F. 1991. Cultura de empresa e identidades profissionais, Revista de Administração da USP 26(2): 40-59.

Berry, D.; Towill, D. R.; Wadsley, N. 1994. Supply chain management in the electronics products industry, International Journal of Physical Distribution and Logistics Management 24(10): 20-32. http://dx.doi.org/10.1108/09600039410074773

Brasil. 2010a. Ministério do Desenvolvimento, Indústria e Comércio Exterior [online], [cited 30 November 2010]. Available from Internet: http://www.mdic.gov.br//sitio/interna/interna. php?area $=2$ andmenu $=1103$

Chami Batista, J. 2010. Os efeitos das políticas industriais para o setor de produtos eletrônicos do Brasil, Revista de Economia Política 30(1): 112-123.

Cnm/Dieese. 2010. Setor eletroeletrônico no Brasil - texto de apoio com informações gerais [online], [cited 30 October 2010]. Available from Internet: http://www.imfmetal.org/ files/10041915024410005/Dorival_Jesus_do_Nacimento.pdf

Fantazy, K. A.; Kumar, V.; Kumar U. 2010. Supply management practices and performance in the Canadian hospitality industry, International Journal of Hospitality Management 29(4): 685-693. http://dx.doi.org/10.1016/j.ijhm.2010.02.001

Fensterseifer, J. E.; Bastos R. M. 1989. A implantação de sistemas MRP de gestão da produção e de materiais nas grandes empresas industriais do Brasil, Revista de Administração da USP 24(1): 11-22.

Ferreira, K. A.; Assumpção, M. R. P. 2005. Logística e troca de informações em empresas automobilísticas e alimentícias, Revista Produção 15(3): 434-447.

Fleury, A. 1999. The changing pattern of operations management in developing country: the case of Brazil, International Journal of Operations and Production Management 19(5/6): 552-564. http://dx.doi.org/10.1108/01443579910260874

Fleury, A.; Fleury, M. T. 2007. The evolution of production systems and conceptual frameworks, Journal of Manufacturing Technology Management 18(8): 949-965.

http://dx.doi.org/10.1108/17410380710828271

Gonçalves, R. R. 1997. O setor de bens de eletrônicos de consumo no Brasil: uma análise de seu desempenho recente e perspectivas de evolução futura, Texto para Discussão 476: 1-20.

Gutierrez, R. M. V.; Alexandre, P. V. M. 2003. Complexo eletrônico brasileiro e competitividade, BNDES Setorial 18: 165-192.

Hauser, G.; Zen, A. C.; Selao, D. C., Garcia, P. L. 2007. A indústria eletroeletrônica no Brasil e na China: um estudo comparativo e a análise das políticas públicas de estímulo a capacidade tecnológica do setor, Journal of Technology Management and Innovation 2(3): 85-96.

Hayes, R. H.; Wheelwright, S. C. 1984. Restoring our competitive edge-competing through manufacturing. New York: John Wiley. 
Helo, P. 2004. Managing agility and productivity in the electronics industry, Industrial Management and Data Systems 104(7): 567-577. http://dx.doi.org/10.1108/02635570410550232

Jabbour, A. B. L. S.; Gomes Filho, A. A.; Viana, A. B. N.; Jabbour, C. J. C. 2011. Measuring Supply Chain Management Practices, Measuring Business Excellence 15(2): 18-31.

http://dx.doi.org/10.1108/13683041111131592

Jansen, L. K. C.; Rotondaro, J. R. G.; Jansen, J. U. 2005. Estratégias de sobrevivência para pequenas e médias empresas em ambientes globalizados: um estudo de caso do setor eletroeletrônico, Gestão \& Produção 12(3): 405-416. http://dx.doi.org/10.1590/S0104-530X2005000300010

Koh, S. S.; Demirbag, M.; Bayraktar, E.; Tatoglu, E.; Zaim, S. 2007. The impact of supply chain management practices on performance of SMEs, Industrial Management and Data Systems 107(1): 103-124. http://dx.doi.org/10.1108/02635570710719089

Krajewski, L.; Ritzman, L.; Malhotra, M. 2009. Administração de produção e operações. São Paulo: Pearson Prentice Hall.

Kronmeyer Filho, O. R.; Fachinello, T.; Kliemann Neto, F. 2004. O mapeamento da cadeia eletrônica no RS: um estudo inicial, in Proceedings of XXIV Encontro Nacional de Engenharia de Produção (Enegep), 02-04 November, 2004 Florianópolis, SC, 3648-3655.

Lankford, W. M.; Johnson, J. E. 2000. EDI via the Internet, Information Management and Computer Security 8(1): 27-30. http://dx.doi.org/10.1108/09685220010312353

Li, S.; Ragu-Nathan, B.; Ragu-Nathan, T. S.; Rao, S. S. 2006. The impact of supply chain management practices on competitive advantage and organizational performance, Omega 34: 107-124. http://dx.doi.org/10.1016/j.omega.2004.08.002

Li, S.; Rao, S. S.; Ragu-Nathan, T. S.; Ragu-Nathan, B. 2005. Development and validation of a measurement instrument for studying supply chain management practices, Journal of Operations Management 23: 618-641. http://dx.doi.org/10.1016/j.jom.2005.01.002

Mafra, R.; Grisci, C. L. I. 2004. Reestruturação produtiva e modos de gestão de pessoas em uma empresa do setor eletro-eletrônico de Santa Catarina, Revista Eletrônica de Administração 10(3): 1-24.

Malhotra, M. K.; Grover, V. 1998. An assessment of survey research in POM: from constructs to theory, Journal of Operations Management 16(4): 407-425.

http://dx.doi.org/10.1016/S0272-6963(98)00021-7

Martins, H. H. T. S. 2001. O processo de reestruturação produtiva e o jovem trabalhador: conhecimento e participação, Tempo Social 13(2): 61-87.

McIvor, R.; Humphreys, P. 2004. Early supplier involvement in the design process: lessons from the electronics industry, Omega 32: 179-199. http://dx.doi.org/10.1016/j.omega.2003.09.005

Mouritsen, J.; Skjott-Larsen, T.; Kotzab, H. 2003. Exploring the contours of supply chain management, Integrated Manufacturing Systems 14(8): 686-695.

http://dx.doi.org/10.1108/09576060310503483

Nassif, A. 2002. Complexo eletrônico brasileiro. BNDES 50 anos: histórias setoriais [online], [cited 10 September 2010]. Available from Internet: http://www.bndespar.com.br

Prentis, E. L. 1987. Operations management taxonomy, Journal of Operations Management 7(1/2): 63-78. http://dx.doi.org/10.1016/0272-6963(87)90007-6

Shunk, D. L.; Carter, J. R.; Hovis, J.; Talwar, A. 2007. Electronics industry drivers of intermediation and disintermediation, International Journal of Physical Distribution and Logistics Management 37(2): 248-261. http://dx.doi.org/10.1108/09600030710742443

Singh, S.; Al-Hakim, L. 2009. Managing supply chain at high technology companies, IEE Computer Society 83: 400-409. http://dx.doi.org/10.1109/COINFO.2009.83

Slack, N.; Chambers, S.; Harland, S.; Harrison, A.; Johnston, R. 1996. Administração da Produção. São Paulo: Atlas. 
Slongo, L. A. 1996. Serviços ao cliente na indústria eletro-eletrônica no Rio Grande do Sul, Revista de Administração da USP 31(4): 57-76.

Sohal, A. S.; Gordon, J.; Fuller, G.; Simen, A. 1999. Manufacturing practices and competitive capability: an Australian study, Technovation 19: 295-304.

http://dx.doi.org/10.1016/S0166-4972(98)00121-7

Spekman, R. E.; Kamauff, Jr, J. W.; Myhr, N.1998. An empirical investigation into supply chain management - a perspective on partnerships, International Journal of Physical Distribution and Logistics Management 28(8): 630-650. http://dx.doi.org/10.1108/09600039810247542

Synodinos, N. E. 2003. The "art" of questionnaire construction: some important considerations for manufacturing studies, Integrated Manufacturing Systems 14(3): 221-237.

http://dx.doi.org/10.1108/09576060310463172

Talamo, J. R.; Carvalho, M. M. 2004. Seleção dos objetivos fundamentais de uma rede de cooperação empresarial, Gestão \& Produção 11(2): 239-250.

Tan, L.; Hwang, A. R. 2002. Imported technology and R\&D in the Taiwanese electronic industry, Review of Development Economics 6(1): 77-90. http://dx.doi.org/ 10.1111/1467-9361.00142

Vianna, N. W. H.; Souza, N. A.; Muritiba, S. N.; Almeida, S. R.; Pereira, L. H. 2007. Indústria eletroeletrônica brasileira: estratégias de entrada e desafios do processo de internacionalização, Revista Eletrônica de Administração 13(4): 1-22.

Yeung, A. C. L.; Cheng, T. C. E.; Lai, K. 2005. An empirical model for managing quality in the electronics industry, Production and Operations Management 14(2): 189-2044.

http://dx.doi.org/10.1111/j.1937-5956.2005.tb00018.x

Sebrae. Critérios e conceitos para classificação de empresas [online], [cited 05 May 2009], Available from Internet: http://www.sebrae.com.br/customizado/estudos-e pesquisas/integra_bia?ident_unico=97.

Ana Beatriz Lopes de Sousa JABBOUR. She has a $\mathrm{PhD}$ in Industrial Engineering from The Federal University of Sao Carlos - UFSCar, Brazil. She is Assistant Professor in Sao Paulo State University. Her research interests include supply chain management and operations management. Dr. Jabbour has articles published in International Journal of Production Economics, Industrial Management \& Data Systems, Measuring Business Excellence, and others journals.

Charbel José Chiappetta JABBOUR. He has a $\mathrm{PhD}$ in Industrial Engineering from The University of Sao Paulo - USP, Brazil. He is Associate Professor in Sao Paulo State University. His research interests include business administration, environmental management in companies and operations management. He has articles published in Journal of Cleaner Production, International Journal of Production Research, Industrial Management \& Data Systems, and others. 